\title{
LITERASI MASYARAKAT TERHADAP PENYEBARAN BERITA-BERITA VIRAL INTERNET DAN HUBUNGANNYA DENGAN KETAHANAN NASIONAL
}

\author{
Abdul Haris Subarjo \\ Departemen Teknik Mesin \\ Sekolah Tinggi Teknologi Adisutjipto \\ J1. Raya Janti Blok R Lanud Adisucipto \\ Email: ab.haris.79@gmail.com
}

\begin{abstract}
STTA is an academic institution, because of the resion important to research in this institution. The research has aim to known literacy profile in academic society. Focus this research is information in internet or social media and reseliance. This research is a descriptive. The research focused in social media viral news with the reseliance. Sample of the research with the purposive cluster sampling, with the student STTA is a sample. Department is a cluster. Quesioner and writing tes is an instrument. From the data there are many conclution. Improved of information literacy is important to the responden. The benefit from the data, we can knows that information can be fast to transmited. The information can be viral information. But the hoax information can be froud in the society. Thishoax information can be danger to the nasional resilience.
\end{abstract}

\section{Keywords: Literacy, Internet, National Resilience}

1. Pendahuluan

Pada awal tahun 2000 apabila ingin mengetahui kabar/berita yang terjadi di daerah lain membutuhkan waktu yang cukup lama. Bahkan kalau jaraknya berkilokilo meter dari tempat tinggal kita membutuhkan waktu berhari-hari sampai bertahun-tahun. Namun pada masa sekarang hal tersebut tidak terjadi lagi. Jarak tidak lagi menjadi penghambat untuk mengetahui berbagai informasi dengan cepat.

Berbagai informasi atau kejadian di propinsi lain di Indonesia dalam hitungan detik dapat diketahui. Bahkan kejadian yang terjadi di negara lain yang jaraknya berjutajuta kilometer juga dapat dalam hitungan detik. Hal tersebut dapat terjadi nyata dan bukan mimpi. Namun suatu mimpi yang menjadi nyata melalui bantuan Internet. Internet telah merubah situasi dan kebiasaan masyarakat.

Internet saat ini bukan menjadi hal yang mewah atau hal yang aneh lagi, hampir setiap orang memanfaatkan internet. Pemanfaatan internet tidak hanya kalangan terdidik, orang kaya dan para eksekutif di perusahaan besar, namun internet juga dimanfaatkan oleh masyarakat tanpa batasan selama dapat terhubung dengan internet. Bahkan pada masyarakat yang memiliki tingkat pendidikan rendah serta yang secara ekonomi pas-pasan. Di kalangan akademisi termasuk pelajar dan mahasiswa internet sudah lazim digunakan. Biasanya kalangan akademisi internet dipergunakan untuk mencari informasi dan mencari sumbersumber pustaka dalam rangka mengerjakan tugas-tugasnya.

Internet adalah kumpulan atau jaringan dari jaringan komputer yang ada di seluruh dunia. Dalam hal ini komputer yang sebelumnya stand-alone kini dapat berhubungan langsung dengan host-host atau komputer-komputer lain. [1] Internet sebenarnya mengacu kepada istilah untuk menyebut sebuah jaringan, bukannya suatu aplikasi tertentu. Oleh karenanya, internet tidaklah bermanfaat tanpa adanya aplikasi yang sesuai.[1] Beraneka ragam tingkat pendidikan dan pekerjaannya juga memberikan andil dalam menyikapinya. Seiring dengan kebutuhan para penggunanya maka muncullah beragam aplikasi yang memanfaatkan internet. Termasuk aplikasi yang digunakan untuk berkomunikasi dan berbagai media sosial. Kemudahan untuk 
saling memberikan informasi melalui media sosial memberikan dampak positif dan negatif.

Dampak positifnya, informasiinformasi penting dapat segera diketahui dan ditindaklanjuti, namun dampak negatifnya tidak semua informasi yang disajikan tersebut benar. Demikian pula yang terjadi pada akhir -akhir ini, beragam informasi mengalir deras dengan beragam kepentingan. Setiap orang saat ini seakan dapat memberikan informasi, pendapat maupun tanggapan tanpa adanya kendala meskipun pemerintah berupaya memberikan rambu-rambu melalui undang-undang ITE.

Dalam kenyataannya seringkali informasi yang ada di media sosial tersebut menimbulkan kegaduhan, keresahan dan dapat memecah belah masyarakat. Beragam kabar yang belum diselidiki kebenarannya terpampang. Sayangnya beragam informasi tersebut dengan mudah dipercaya oleh masyarakat secara instan tanpa upaya untuk mencerna secara mendalam dan mencari tahu ke sumber-sumber informasi lain yang valid. Literasi merupakan salah satu komponen yang disorot oleh negra-negara di dunia. Tingkat literasi suatu negara menunjukkan kemampuan dari warga negaranya dalam menelaah, mengkaji, menyaring, menyebarluarkan suatu informasi serta mengambil keputusan dan bertindak berdasarkan informasi tersebut. Indonesia termasuk negara yang memiliki tingkat literasi rendah berdasarkan penelitian yang dilakukan oleh PISA.

Berdasarkan hal tersebut maka perlu dilakukan penelitian yang mengungkap bagaimana profil literasi masyarakat terhadap penyebaran berita dan informasi di internet dalam kaitannya dengan ketahanan nasional.

Literasi merupakan kemampuan seseorang dalam mengolah dan memahami informasi saat melakukan proses membaca dan menulis. Literasi memerlukan serangkaian kemampuan kognitif, pengetahuan bahasa tulis dan lisan. Istilah literasi atau dalam bahasa Inggris literacy berasal dari bahasa Latin literatus, yang berarti "a learned person" atau orang yang belajar. Dalam bahasa Latin juga dikenal dengan istilah littera (huruf) yang artinya melibatkan penguasaan sistem-sistem tulisan dan konvensi-konvensi yang menyertainya.

Awalnya literasi dimaknakan secara sempit sebagai "melek huruf" yaitu suattu kemampuan dalam hal membaca, namun kemudian ditambahkan juga dengan kemampuan menulis. Dalam perkembangan waktu, pengertian literasi bukan hanya berkaitan dengan keaksaraan atau bahasa, namun berkembang menjadi konsep fungsional pada dasawarsa 1960-an yaitu literasi berkaitan dengan berbagai fungsi dan keterampilan hidup. Literasi dipahami sebagai seperangkat kemampuan mengolah informasi, jauh di atas kemampuan menganalisa dan memahami bahan bacaan. dengan kata lain, literasi bukan hanya tentang membaca dan menulis, tetapi juga mencakup bidang lain, seperti ekonomi, matematika, sains, sosial, lingkungan, keuangan, bahkan moral (moral literacy). Kern mendefinisikan istilah literasi sebagai berikut:

Literacy is the use of socially-, and historically-, and culturally-situated practices of creating and interpreting meaning through texts. It entails at least a tacit awareness of the relationships between textual conventions and their context of use and, ideally, the ability to reflect critically on those relationships. Because it is purpose-sensitive, literacy is dynamic - not static - and variable across and within discourse communities and cultures. It draws on a wide range of cognitive abilities, on knowledge of written and spoken language, on knowledge of genres, and on cultural knowledge. [2]

Secara bebas dapat diterjemahkan bahwa literasi merupakan penggunaan praktik situasi sosial, dan historis, serta kultural dalam menciptakan dan menginterpretasikan makna melalui teks (baik lisan maupun tulisan). Literasi memerlukan setidaknya sebuah kepekaan yang tak terucap tentang hubungan antara konvensi tekstual dan konteks penggunaanya serta idealnya kemampuan untuk berefleksi secara kritis tentang hubungan itu. Karena peka dengan maksud/tujuan, literasi itu bersifat dinamis tidak statis - dan dapat bervariasi di antara 
dan di dalam komunitas dan kultur / wacana. Literasi memerlukan serangkaian kemampuan kognitif, pengetahuan bahasa tulis dan lisan, pengetahuan tentang genre, dan pengetahuan kultural.

Chaidir dalam bukunya "Bela Negara, Implementasi dan Pengembangannya" menyatakan bahwa Ketahanan Nasional dipandang sebagai gambaran kondisi dinamis dari sistem kehidupan nasional yang bercirikan keuletan dan ketangguhan yang mengandung kemampuan untuk mengembangkan kekuatan nasional. Upaya mewujudkan, memelihara dan meningkatkan ketahanan nasional dilakukan melalui proses pembangunan. Keberhasilan melaksanakan pembangunan nasional berarti akan meningkatkan kondisi ketahanan nasional. Dengan meningkatnya kondisi ketahanan nasional sebagai output dari pembangunan nasional itu akan lebih meningkatkan upaya bangsa untuk menghadapi segala macam bentuk ancaman, gangguan, hambatan dan tantangan, hal ini berarti akan lebih mendorong laju pembangunan nasional.[3]

Ketahanan nasional adalah suatu kondisi dinamik bangsa Indonesia yang berisi keuletan dan ketangguhan yang mengandung kemampuan mengembangkan kekuatan nasional, dalam menghadapi dan mengatasi segala tantangan, ancaman, hambatan serta gangguan yang datang dari dalam maupun luar negeri, baik secara langsung maupun tidak langsung membahayakan kelangsungan kehidupan ekonomi bangsa dan negara Indonesia berdasarkan Pancasila dan UUD 45.[4]

Ketahanan nasional merupakan akumulasi dari nilai ketahanan-ketahanan pada tingkat di bawahnya yang membentuk struktur piramidal, dengan jenjang seperti; ketahanan pribadi, ketahanan keluarga, ketahanan lingkungan, dan ketahanan wilayah.[5]

1. Metode Penelitian

Metode yang digunakan dalam penelitian berjudul "Literasi masyarakat terhadap penyebaran berita-berita viral internet dan hubungannya dengan ketahanan nasional "sebagai berikut:

a. Jenis penelitian

Penelitian ini merupakan suatu deskriptif yang mengungkap profil literasi masyarakat khususnya pada masyarakat akademik di STTA terhadap penyebaran berita-berita viral internet dan hubungannya dengan ketahanan nasional.

b. Populasi dan sampel penelitian

Dalam penelitian ini sebagai populasi adalah mahasiswa STTA dan sampel dalam penelitian adalah mahasiswa STTA yang berasal dari tiga program studi yaitu teknik mesin, teknik elektro dan teknik penerbangan.

c. Teknik pengambilan sampel

Dari populasi yang ada yakni mahasiswa STTA sebagai masyarakat akademik di lingkungan kampus dan dari populasi tersebut perlu diambil sampel. Sampel diambil dengan teknik purposive cluster sampling pada mahasiswa STTA. Dengan program studi sebagai cluster-nya.

d. Instrumen penelitian

Penelitian ini menggunakan intrumen penelitian untuk mengumpulkan dan memperoleh informasi yang diperlukan. Instrumen yang digunakan adalah angket dan tes tulis.

e. Teknik analisis data.

Setelah data diperoleh maka dilakukan beberapa rangkaian analisa data yang meliputi kegiatan kategorisasi data, mendeskripsikan setiap kategori, sinkronisasi temuan, merumuskan temuan-temuan

2. Hasil

Hasil penelitian disajikan dalam bentuk table 1 dibawah ini. 
Tabel 1. Frekuensi Penelusuran dan Penyebaran Informasi yang dilakukan oleh responden

\begin{tabular}{|c|c|c|c|}
\hline Pertanyaan & Sering & Jarang & $\begin{array}{l}\text { Tidak } \\
\text { pernah }\end{array}$ \\
\hline 1. Apakah anda mengikuti perkembangan informasi setiap hari? & $88 \%$ & $9 \%$ & $3 \%$ \\
\hline 2. Apakah anda dalam keseharian menggunakan sosial media? & $95 \%$ & $5 \%$ & $0 \%$ \\
\hline $\begin{array}{l}\text { 3. Apakah anda hanya menggunakan } 1 \text { sosial media untuk mencari } \\
\text { informasi? }\end{array}$ & $4 \%$ & $14 \%$ & $82 \%$ \\
\hline $\begin{array}{l}\text { 4. Apakah anda menyimpan informasi yang diperoleh untuk anda } \\
\text { sendiri? }\end{array}$ & $5 \%$ & $7 \%$ & $88 \%$ \\
\hline $\begin{array}{l}\text { 5. Apakah anda membagi informasi yang anda peroleh dengan teman- } \\
\text { teman atau relasi anda? }\end{array}$ & $85 \%$ & $5 \%$ & $10 \%$ \\
\hline $\begin{array}{l}\text { 6. Apakah anda melakukan penelusuran kebenaran informasi yang } \\
\text { anda peroleh? }\end{array}$ & $6 \%$ & $9 \%$ & $85 \%$ \\
\hline $\begin{array}{l}\text { 7. Apakah anda mengalami kesulitan dalam mengakses informasi yang } \\
\text { dibutuhkan? }\end{array}$ & $3 \%$ & $5 \%$ & $92 \%$ \\
\hline 8. Apakah sumber informasi yang anda peroleh melalui media cetak? & $1 \%$ & $4 \%$ & $95 \%$ \\
\hline $\begin{array}{l}\text { 9. Apakah anda lebih banyak menggunakan sumber informasi secara } \\
\text { online? }\end{array}$ & $97 \%$ & $2 \%$ & $1 \%$ \\
\hline
\end{tabular}

3. Pembahasan

Terdapat tujuh prinsip pendidikan literasi yang diambil dari definisi Kern (2000) yaitu:

1. Literasi melibatkan interpretasi, dimana penulis/pembicara dan pembaca/pendengar berpartisipasi dalam tindak interpretasi.

2. Literasi melibatkan kolaborasi, sehingga terdapat kerjasama antara dua pihak yakni penulis/pembicara dan pembaca/pendengar dalam upaya mencapai suatu pemahaman bersama.

3. Literasi melibatkan konvensi, maksudnya orang-orang membaca dan menulis atau menyimak dan berbicara itu ditentukan oleh konvensi/kesepakatan kultural (tidak universal) yang berkembang melalui penggunaan dan dimodifikasi untuk tujuan-tujuan individual.

4. Literasi melibatkan pengetahuan kultural, bermakna bahwa dalam membaca dan menulis atau menyimak dan berbicara berfungsi dalam system, sikap, keyakinan, kebiasaan, cita-cita, dan nilai tertentu. Sehingga orang yang berada di luar suatu sistem budaya itu rentan salah dipahami oleh orang-orang yang berada dalam sistem budaya tersebut.

5. Literasi melibatkan pemecahan masalah, hal tersebut dapat dipahami karena kata selalu melekat pada konteks linguistik dan situasi yang melingkupinya, maka tindak menyimak, berbicara, membaca, dan menulis melibatkan upaya membayangkan hubungan-hubungan di antara kata, frase, kalimat, unit makna, teks, dan dunia. Sehingga adanya suatu upaya membayangkan/memikirkan/memperti mbangkan dan menggunakan pengetahuan yang dimiliki merupakan suatu bentuk pemecahan masalah.

6. Literasi melibatkan refleksi dan refleksi diri. Dimana para pembaca/pendengar dan penulis/pembicara memikirkan bahasa dan hubungan dunia dan diri mereka sendiri. Mendudukkan diri berada dalam situasi komunikasi memikirkan apa yang telah dikatakan, bagaimana mengatakannya, dan mengapa mengatakan hal tersebut

7. Literasi melibatkan penggunaan bahasa. Literasi tidak terbatas pada sistemsistem bahasa (lisan/tertulis) melainkan mensyaratkan pengetahuan tentang bagaimana bahasa itu digunakan baik dalam konteks lisan maupun tertulis untuk menciptakan sebuah wacana.

Menurut kamus online MerriamWebster, Literasi berasal dari istilah latin 'literature' dan bahasa inggris 'letter'. Literasi merupakan kualitas atau kemampuan melek huruf/aksara yang di dalamnya meliputi kemampuan membaca dan menulis. Namun lebih dari itu, makna 
literasi juga mencakup melek visual yang artinya "kemampuan untuk mengenali dan memahami ide-ide yang disampaikan secara visual (adegan, video, gambar)."

Media yang sering dibuka untuk mencari informasi adalah media online dengan alasan mudah menggunakannya, serta selalu dibawa. Informasi dapat diperoleh dari berbagai sumber online. Namun ternyata kemudahan penelusuran media tersebut belum diimbangi dengan melakukan penelusuran kebenaran berita atau informasi. Para narasumber hanya sedikit yang melakukan penelusuran lanjut sebagian besar responden menyatakan langsung membagikan informasi atau berita yang diperoleh melalui komunitas atau grup yang responden ikuti. Saat diwawancara lanjut apakah tidak khawatir bila berita atau informasi tersebut tidak benar, responden menyatakan "biasanya bila ada yang tidak benar akan ada pemberitahuan dari anggota grup di grup atau komunitas mereka".

Berdasarkan temuan-temuan tersebut maka dapat diperoleh informasi pentingnya menggalakkan literasi informasi di masyarakat, karena apabila terdapat informasi yang tidak benar dan berpotensi menimbulkan keresahan dimasyarakat ini dapat mengancam persatuan dan ketahanan nasional. Berita negatif yang tidak benar dapat menimbulkan kebingungan dimasyarakat serta keresahan. Ketahanan nasional sangat berkaitan dengan hal ini.

Berdasarkan hasil penelitian diperoleh informasi bahwa $88 \%$ responden tidak pernah menyimpan informasi yang diperoleh untuk diri sendiri, kecenderungan responden $85 \%$ akan membagi informasi yang diperoleh kepada teman atau relasinya, $85 \%$ responden juga tidak melakukan penelusuran lebih lanjut mengenai informasi yang diperoleh, kecenderungan $88 \%$ responden mengikuti perkembanga informasi setiap hari.

Hal ini menunjukkan bahwa informasi melalui media sosial tidak membutuhkan waktu lama untuk menyebarkannya, namun kebenaran informasi yang tersebar belum jelas kebenarannya.

4. Kesimpulan

Literasi informasi diperlukan dalam mengakses, memanfaatkan dan menyebarkan berbagai informasi yang diperoleh sehingga tidak dengan mudah menyebarkan berbagai informasi tanpa memeriksa lebih dahulu kebenarannya. Penyebaran berbagai informasi yang benar serta santun akan membuat penerima informasi menalar dengan baik sehingga tidak mudah terpancing berbuat hal yang meresahkan. Dengan demikian maka literasi informasi sangat penting untuk mendukung ketahanan nasional karena tanpa pemahaman yang baik terutama berkaitan dengan berita viral dapat menimbulkan keresahan yang pada akhirnya dapat berpotensi terhadap ketahanan nasional.

Dari data-data yang diperoleh, dapat disimpulkan perlunya kemampuan literasi dari para responden untuk memahami informasi yang didapatnya. Keuntungan yang dapat dilihat berdasarkan data tersebut informasi cepat diperoleh dan dapat menjadi viral. Namun kerugiannya apabila terdapat informasi yang tidak benar dan berpotensi menimbulkan keresahan akan cepat tersebar dan dapat berpotensi mengancam ketahanan nasional.

\section{Saran}

Perlu dilakukan penelitian lebih lanjut tentang dampak dari penyebaran informasi viral melaui internet. Baik penelitian mengenai dampak negatif penyebaran informasi maupun dampak positif.

\section{Ucapan Terimakasih}

Penulis mengucapkan terima kasih kepada STTA yang telah memberi dukungan financial terhadap penelitian ini.

\section{DAFTAR PUSTAKA}

[1] Sinarmata. J., 2006, Pengenalan Teknologi Komputer dan Informasi, Andi Offset, Yogyakarta, p.281,285

[2] Kern. R., 2000, Literacy and Language Teaching. Oxford University Press.

[3] Chaidir, Basrie., 1998, Bela Negara, Implementasi dan Pengembangannya, UI Pres, Jakarta.p.340-369

[4] Subarjo. AH, 2012, Peran Kelompok Tani "Mina Perkasa" dalam menunjang Ketahanan Ekonomi Anggota Kelompok (Studi di Purwomartani, Kalasan, Sleman, Daerah Istimewa Yogyakarta. Tesis 
dipublikasikan terbatas, UGM: Relokasi Pedagang Pasca Peristiwa

Yogyakarta.p.9
[5] Purwoko. AA, 2012, Makna Pasar Tradisional dalam Perspektif Ketahanan Ekonomi Ketahanan Ekonomi Keluarga (Studi Kasus Kebakaran Pasar Rejowinangun Kota Magelang Provinsi Jawa Tengah. Tesis dipublikasikan terbatas. UGM: Yogyakarta.p. 18 